\title{
The potential and limitations of plasma BNP measurement in the diagnosis, prognosis, and management of children with heart failure due to congenital cardiac disease: an update
}

\author{
Massimiliano Cantinotti $\cdot$ Yuk Law • \\ Simona Vittorini - Maura Crocetti • \\ Marotta Marco • Bruno Murzi • Aldo Clerico
}

Published online: 29 January 2014

(c) Springer Science+Business Media New York 2014

\begin{abstract}
The aim of this article is to review the diagnostic and prognostic relevance of measurement of brain natriuretic peptide (BNP) and N-terminal pro-brain natriuretic peptide (NT-proBNP) in pediatric patients with heart failure caused by various acquired and congenital heart diseases (CHD). In January 2013, we performed a computerized literature search in the National Library of Medicine (PubMed access to MEDLINE citations; http:// www.ncbi.nlm.nih.gov/PubMed/). The search strategy included a mix of Medical Subject Headings and free-text terms for the key concepts, starting from BNP assay and 'NT-proBNP assay', children, CHD. The search was further refined by adding the keywords neonate/s, newborn/s, heart failure, cardiomyopathy, screening, prognosis, follow-up, and management. BNP values are age and method dependent, even in pediatric populations. Regardless of age, there is great variability in BNP/NT-proBNP values within CHD characterized by different hemodynamic and clinical conditions. There is enough evidence to support the use of BNP/NT-proBNP as an adjunctive marker in the integrated evaluation of patients with congenital and acquired heart disease to help define severity and progression of heart failure as well in the monitoring of
\end{abstract}

M. Cantinotti ( $)$ - S. Vittorini · M. Crocetti · M. Marco ·

B. Murzi · A. Clerico

Fondazione Toscana G. Monasterio, Ospedale del Cuore,

via Aurelia Sud, 54100 Massa, Pisa, Italy

e-mail: cantinotti@ftgm.it

Y. Law

Seattle Children Hospital, University of Washington School of Medicine, Seattle, WA, USA

A. Clerico

Scuola Superiore Sant'Anna, Pisa, Pisa, Italy response to treatment. BNP/NT-proBNP can also be used for the screening of heart failure and as a prognostic marker in children undergoing cardiac surgery; however, to date, there are studies with heterogeneous patient groups, and diverse outcome measures selected are still few. BNP/NTproBNP can be used as adjunctive markers in the integrated screening, diagnosis, management, and follow-up of children with heart failure caused by various acquired and congenital heart disease.

Keywords Biomarker - Natriuretic peptides - BNP . Children $\cdot$ Neonates $\cdot$ Congenital heart disease $\cdot$ Heart failure

$\begin{array}{ll}\text { Abbreviations } \\ \text { BNP } & \text { Brain natriuretic peptide } \\ \text { CHD } & \text { Congenital heart disease } \\ \text { HF } & \text { Heart failure } \\ \text { MCS } & \text { Mechanical circulatory support } \\ \text { NT-proBNP } & \text { N-terminal pro-brain natriuretic peptide } \\ \text { NYHA } & \text { New York Heart Association (NYHA) } \\ \text { POCT } & \text { Point-of-care test } \\ \text { RV } & \text { Right ventricle } \\ \text { SV } & \text { Single ventricle } \\ \text { UH } & \text { Univentricular heart }\end{array}$

\section{Background}

Cardiac natriuretic peptides, which include the atrial natriuretic peptide (ANP) and B-type natriuretic peptide (BNP) and their related peptides, constitute a complex family of peptide hormones produced and secreted by the human heart $[1,2]$. The active peptide BNP is produced in human cardiomyocytes by cleavage of the $\mathrm{COOH}$-terminal 
part of the pro-hormone (NT-proBNP), while the N-terminal fragments of the pro-hormone, NT-proBNP, are currently considered inactive [1]. To date, international guidelines are recommending measurements of circulating BNP and NT-proBNP [3, 4] as a biomarker for diagnosis, prognosis, and therapeutic monitoring in adults with cardiac diseases, especially those with acute and chronic heart failure. Accordingly, there has been a growing interest to incorporate the use of BNP/NT-proBNP also in the management of children with cardiomyopathy and congenital cardiac disease (CHD) [2, 5]. However, despite the inflation of single-center pediatric studies, better definition of normative values in children, and the strength of evidence in clinical trials in adults, there still are no large scale or definitive studies to substantiate its utility in the various aspects of heart failure management in children. Here, we will discuss the caveats and challenges to its applicability.

\begin{abstract}
Aims
The overall objective of this article is to provide a critical review of published studies concerning the diagnostic accuracy and prognostic relevance of BNP/NT-proBNP measurements in children with heart failure caused by different types of congenital and acquired cardiac disease. Another purpose is to suggest some pathophysiologic and clinical considerations for future studies in diagnosis, risk stratification, follow-up, and management of pediatric patients with CHD.
\end{abstract}

\section{Methods}

In January 2013, we performed a systematic search for potential publications in the National Library of Medicine (PubMed access to MEDLINE citations; http://www.ncbi. nlm.nih.gov/PubMed/). Potential publications were identified from a systematic search in the National Library of Medicine (PubMed access toMEDLINE citations; http:// www.ncbi.nlm.nih.gov/PubMed/) conducted in January 2013. The search strategy included a mix of medical subject headings and free-text terms for the key concepts, starting from BNP assay NT-proBNP assay children, congenital heart disease. The search was further refined by adding the keywords neonate/s, newborn/s, heart failure, cardiomyopathy, screening, prognosis, follow-up, and management. In addition, we identified other potentially relevant publications using a manual search of references from all eligible studies and review articles as well as from the Science Citation Index Expanded on the Web of Science. All reports identified were assessed independently by two authors (i.e., MC and YL) and underwent a consensus procedure before being included in the present study. Exclusion criteria for titles and abstracts of articles identified by the search strategy were as follows: case reports, abstracts from meetings, articles concerning children without congenital or acquired heart disease, or reports were in languages other than English. Of the two-hundred and twenty-four publications identified for potential inclusion in the study, seventy-eight studies were excluded, leaving 146 publications for analysis.

Following is brief introduction on the most important biochemical and physiological issues of natriuretic peptide production and secretion by cardiac tissue, the first part of this review will take into consideration the critical importance of using reliable references values for BNP in children. In particular, we will focus on the difficulties in establishing reliable cutoff values for CHD. In the second part of our study, we will discuss how plasma BNP concentrations can vary in children with heart failure due to acquired and congenital heart disease according to different hemodynamic conditions and how BNP may aid in the diagnosis, stratification, and prognosis of such diseases.

\section{The physiological role of BNP}

Natriuretic peptides are mainly produced and secreted by cardiomyocytes from the atria (atrial natriuretic peptide, ANP) and ventricles (BNP and NT-proBNP) [1]. Human $\mathrm{BNP}$ is synthesized as a 134-amino acid (aa) precursor protein (pre-NT-proBNP) and subsequently processed during secretion to form a 108-aa peptide, NT-proBNP (Fig. 1). The hormone precursor NT-proBNP is cleaved enzymatically by corin, a convertase produced in cardiomyocytes, to form the 76-aa N-terminal peptide (i.e., NTproBNP) and the C-terminal biologically active 32-aa BNP.

Normal ventricular myocardium may produce only a limited amount of BNP in response to an acute stimulation such as through myocardial stretch, probably via a constitutive secretory pathway, while upregulation and the secretion of additional amounts occur after chronic stimulation through the interaction of the myocardium with the neurohormonal and immunological systems in heart failure [1]. Accordingly, BNP plasma concentrations fluctuate widely and according to patho-physiologic stimuli and cardiovascular hemodynamic both in healthy subjects and in patients with heart failure [1]. However, the bioactive hormone BNP has shorter plasma half-life compared to NT-proBNP. Consequently, BNP also has lower plasma concentration $[1,6]$. In particular, it is estimated that BNP has a plasma half-life of about 15-20 min, while that of NT-proBNP is more than $60 \mathrm{~min}$ in healthy subjects $[1,6]$. Furthermore, there is likely significant infra-individual 


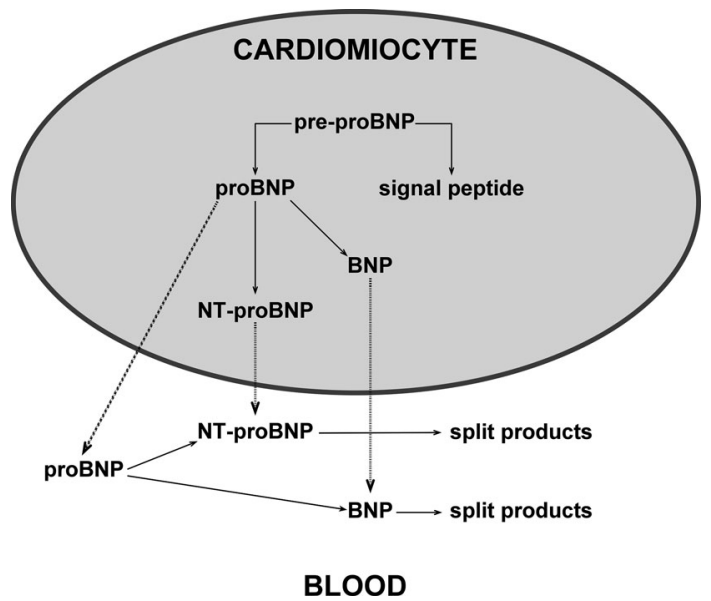

Fig. 1 Schematic representation of production/secretion pathways of B-type natriuretic hormone and its related peptides. Human BNP is synthesized as a 134-amino acid (aa) precursor protein (pre-NTproBNP) and is subsequently processed during secretion to form the 108-aa peptide, NT-proBNP. The pro-peptide hormones of the cardiac natriuretic peptides can be enzymatically cleaved by at least two proprotein convertases produced in the cardiomyocytes, such as corin and furin. In particular, NT-proBNP is processed to form the 76-aa $\mathrm{N}$-terminal peptide (i.e., NT-proBNP), and then the biologically active 32-aa C-terminal peptide (i.e., BNP). BNP has a shorter plasma halflife (about $15-20 \mathrm{~min}$ vs. 1 or $2 \mathrm{~h}$ ) and consequently lower plasma concentration, compared to NT-proBNP. Moreover, the intact NTproBNP 108-aa peptide is also present in plasma, especially of patients with heart failure, in both glycosylated and non-glycosylated form

biological variability (CVi), ranging from 30 to $50 \%$ which may have clinical relevance [6].

\section{Reference range values}

Plasma BNP and NT-proBNP values highly depend on age [1, 2, 6-33]. In particular, considering the pediatric age, plasma BNP concentrations are very high during the first 4 days of life and then rapidly fall during the first week, with a further slower progressive reduction throughout the first month of life (Table 1; Fig 2). After the first month of life, BNP concentrations remain steady, without any significant changes, between 31 days and 12 years of age. Up to 10-14 years of age, there are generally.

In contrast to adults, no gender-related differences in BNP values were reported up to 10-14 years of age $[1,13]$. The gender-related effects observed during adolescence and sexual maturation are probably due to the action of steroid sex hormones [9, 20, 21, 34].

BNP/NT-proBNP concentrations can however be affected by several confounding factors. In particular, higher plasma peptide concentrations were reported in newborn twins compared with singletons, as well as in infants of mothers with type 1 diabetes [28-30], with prematurity, intrauterine growth retardation, caesarian section following uterine contraction, and antenatal stress conditions [31]. Moreover, it is well known that circulating concentrations of BNP and NT-proBNP in pediatric and adult patients can be affected by several extra-cardiac conditions including pulmonary diseases, endocrine and metabolic disorders, liver cirrhosis with ascites, renal failure, inflammatory diseases, use of cardiotoxic drugs, anemia, obesity, severe infections, and cardiac trauma. It is also important to note that BNP levels are strongly method dependent because different immunoassays methods use different antibodies and calibration materials; as a result, the reference ranges change according to the method used (Table 1).), whereas reference ranges for NT-proBNP measurements are not affectedsince all immunoassays use the same antibodies and calibration materials (Roche Diagnostics), providing comparable values across studies (Table 1).

\section{Specific blood BNP measurements}

From an analytical standpoint, it is important to be aware that not only are BNP and NT-proBNP not the same analyte and cannot be converted using a formula, but that the methods of detection can produce different results both in pediatric and adult subjects [9-36]. Considering with specific reference to pediatric subjects, BNP values reported by Soldin et al. [20] obtained with a point-of-care test (POCT) method (TRIAGE BNP test, Biosite, Alere Inc., USA.) showed a similar time course, although with greatly higher values than those reported by Cantinotti et al. [32], who measured BNP using an automated platform (TRIAGE BNP assay by Access platform, Beckman Coulter, Inc. Brea, CA, USA) despite both assays had used the same antibodies for BNP detection. Moreover, NT-proBNP values measured with the same ECLIA method (Roche Diagnostics, Basel, Schweiz) are very similar among the reported studies $[8,13,15-17]$, while the results obtained with the dimension platform (Siemens Healthcare Diagnostics Inc. Tarrytown, NY, USA) by Soldin et al. [20] show significantly higher values. Therefore, clinicians should use great care when comparing results obtained by laboratories using different methods.

\section{BNP in CHD and cardiomyopathy}

From a patho-physiologic standpoint CHD may be characterized by: (1) increased volume overload (i.e., defects characterized by left-to-right shunt, such as ventricular septal defect, patent ductus arteriosus, truncus arteriosus, atrial septal defect, atrio-ventricular septal defects); (2) pressure overload involving the left ventricle (i.e., aortic stenosis, aortic coarctation) or the right ventricle (i.e., tetralogy of Fallot, pulmonary stenosis); (3) complex 
Table 1 Reference values for BNP and NT-proBNP immunoassay in healthy neonates, infants, and children

Part A: BNP assays (M: males, F: females)

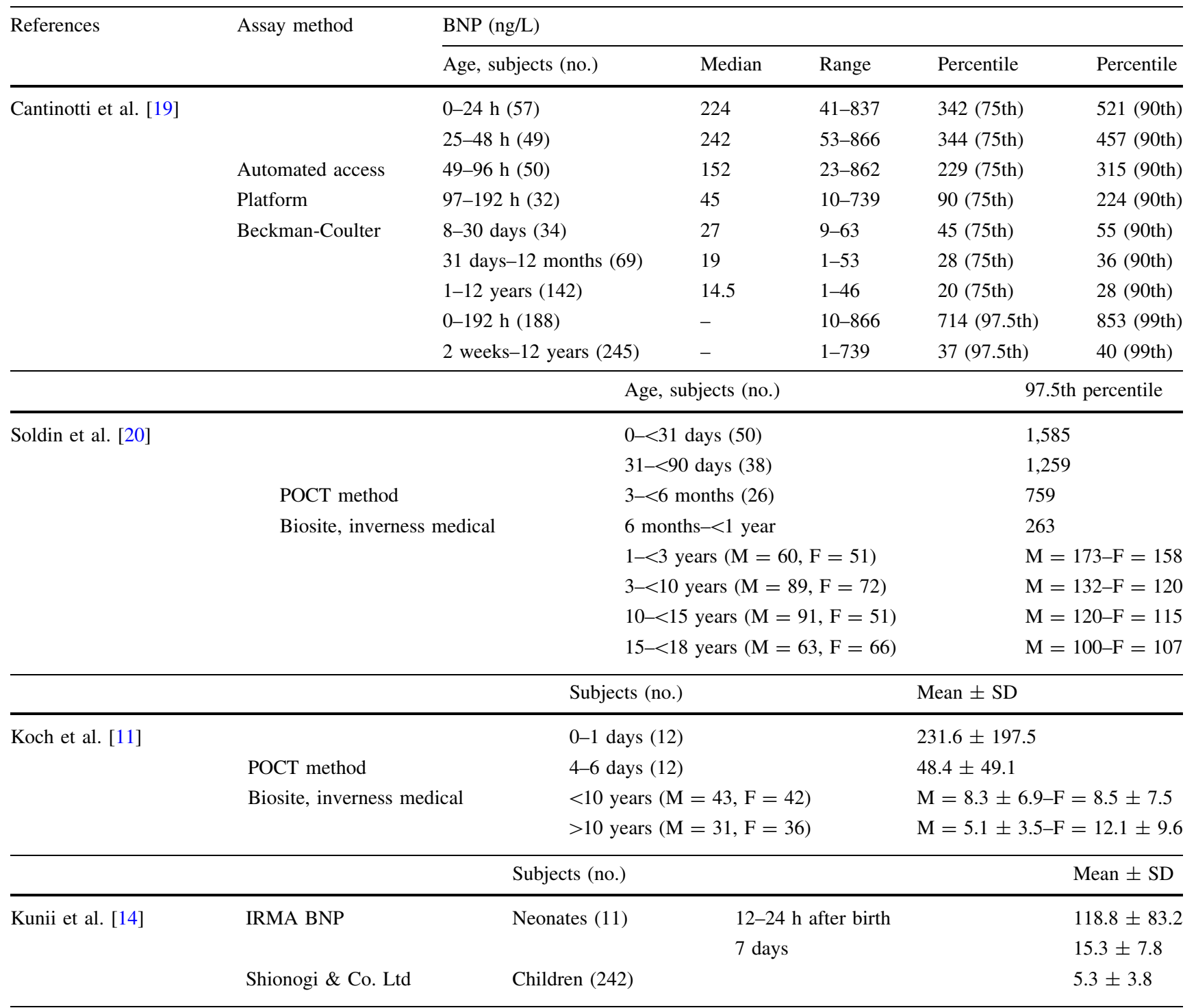

Part B: NT-proBNP assays (M: males, F: females)

\begin{tabular}{|c|c|c|c|c|c|c|}
\hline \multirow[t]{2}{*}{ Reference } & \multirow[t]{2}{*}{ Assay method } & \multicolumn{5}{|l|}{ NT-proBNP (ng/L) } \\
\hline & & Age, subjects (no.) & Median & Range & $\begin{array}{l}\text { 95th } \\
\text { percentile }\end{array}$ & $\begin{array}{l}97.5 \text { th } \\
\text { percentile }\end{array}$ \\
\hline \multirow[t]{7}{*}{ Nir et al. [8] } & & 0-2 days (43) & 3,183 & $260-13,224$ & 11,987 & 13,222 \\
\hline & & 3-11 days (84) & 2,210 & $28-7,250$ & 5,918 & 6,502 \\
\hline & ECLIA method & $>1$ month $-\leq 1$ year $(50)$ & 141 & $5-1,121$ & 646 & 1,000 \\
\hline & Roche diagnostic & $>1-\leq 2$ years $(38)$ & 129 & $31-657$ & 413 & 675 \\
\hline & & $>2-\leq 6$ years $(81)$ & 70 & $5-391$ & 289 & 327 \\
\hline & & $>6-\leq 14$ years $(278)$ & 52 & $5-391$ & 157 & 242 \\
\hline & & $>14-\leq 18$ years $(116)$ & 34 & $5-363$ & 158 & 207 \\
\hline
\end{tabular}


Table 1 continued

\begin{tabular}{|c|c|c|c|c|c|c|}
\hline \multirow[t]{2}{*}{ Reference } & \multirow[t]{2}{*}{ Assay method } & \multicolumn{5}{|l|}{ NT-proBNP (ng/L) } \\
\hline & & Age, subjects (no.) & Median & Range & $\begin{array}{l}\text { 95th } \\
\text { percentile }\end{array}$ & $\begin{array}{l}97.5 \text { th } \\
\text { percentile }\end{array}$ \\
\hline \multirow[t]{12}{*}{ Albers et al. [17] } & \multirow{12}{*}{$\begin{array}{l}\text { ECLIA method } \\
\text { Roche diagnostic }\end{array}$} & $1-3$ years $(13)$ & & $5-391.5$ & & 319.9 \\
\hline & & $4-6$ years $(21)$ & & & & 189.7 \\
\hline & & $7-9$ years $(32)$ & & & & 144.7 \\
\hline & & 10 years $(11)$ & & & & 112.4 \\
\hline & & 11 years (69) & & & & 317.1 \\
\hline & & 12 years $(21)$ & & & & 186.4 \\
\hline & & 13 years $(23)$ & & & & 369.9 \\
\hline & & 14 years $(18)$ & & & & 362.8 \\
\hline & & 15 years $(24)$ & & & & 216.7 \\
\hline & & 16 years $(24)$ & & & & 206.0 \\
\hline & & 17 years $(24)$ & & & & 134.9 \\
\hline & & 18 years $(12)$ & & & & 114.9 \\
\hline \multirow[t]{2}{*}{ Nir et al. [8] } & ECLIA method & $1-5$ days $(20)$ & 1,638 & & & \\
\hline & Roche diagnostic & 4 months-15 years $(58)$ & 780 & $5-391$ & 348.6 & \\
\hline \multirow[t]{2}{*}{ Rauh et al. [15] } & ECLIA method & $<1$ month (13) & & $1,121-7,740$ & & 229 (1 year) \\
\hline & Roche diagnostic & 4 months-18 years $(78)$ & 62.3 & $11-379$ & & 48 (16 years) \\
\hline \multirow[t]{11}{*}{ Schwachtgen et al. [16] } & \multirow{11}{*}{$\begin{array}{l}\text { ECLIA method } \\
\text { Roche diagnosti }\end{array}$} & Umbilical cord (62) & 668 & $281-2,595$ & & \\
\hline & & $0-1$ days $(8)$ & 4,558 & $273-13,224$ & & \\
\hline & & $2-3$ days (40) & 2,492 & $621-8,122$ & & \\
\hline & & 4-8 days (11) & 1,321 & $243-4,130$ & & \\
\hline & & 9-365 days (26) & 157 & $48-739$ & & \\
\hline & & $10-13$ years $(55)$ & 77 & $5-675$ & & \\
\hline & & $10-13$ years $F(16)$ & 43 & $5-157$ & & \\
\hline & & 10-13 years M (14) & 30 & $8-150$ & & \\
\hline & & $13-18$ years $F(11)$ & 68 & $9-162$ & & \\
\hline & & $13-18$ years $M(15)$ & 23 & $5-161$ & & \\
\hline & & $0-<31$ days $(\mathrm{M}=46, \mathrm{~F}=53)$ & & & & $\begin{array}{r}M=28,183, \\
F=35,481\end{array}$ \\
\hline
\end{tabular}

cyanotic CHD (i.e., univentricular heart, transposition of the great arteries) [2].

Several studies [32, 33, 37-39] indicate that BNP concentrations are high in neonates and children with CHD and are higher in those with left ventricular volume overload as compared to those with right ventricular volume or pressure overload. Furthermore, BNP values are higher in diseases characterized by left ventricular pressure overload than in diseases with right ventricular pressure overload. In diseases with volume overload, BNP values are generally positively correlated with the magnitude of left-to-right shunt, pulmonary artery pressure, pulmonary vascular resistance, and end-diastolic volume [37, 40, 41].

In neonates, BNP/NT-proBNP values may be employed for the diagnosis of significant left-to-right shunts and to determine the need for intervention as in the case of ductal closure [42-47]. On average, pediatric patients with complex CHD show significantly higher BNP concentrations compared with those with simple cardiac defects, such as patent ductus arteriosus and atrial or ventricular septal defects [2, 32, 37]. It is still unclear, however, whether there is a difference in BNP expression and production between univentricular heart (UH) defects of right ventricular versus left ventricular morphology [48, 49].

As to BNP values in children with various cardiomyopathies, data are few [44-62]. BNP values are usually higher with decreased ejection fraction, enlarged left ventricular dimensions, and abnormal diastolic indices assessed by echocardiography [50, 52]. In children with hypertrophic cardiomyopathy, BNP values were able to predict disease severity, independently correlated with various echocardiographic parameters including indices of diastolic function and maximal left ventricular wall thickness [51]. In a study considering children with heart failure 


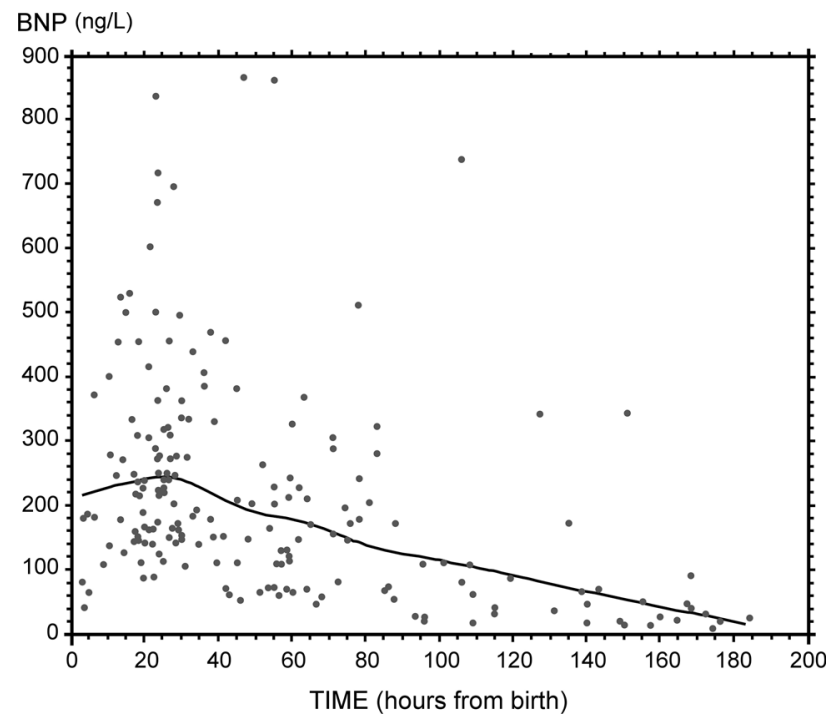

Fig. 2 Plasma BNP in healthy newborns throughout the first days of life. Plasma BNP values were measured in 188 healthy newborns throughout the first days of life. Plasma BNP concentrations are very high during the first 4 days of life, then values fall rapidly during the first week with a further slower progressive reduction throughout the first month of life. Plasma BNP was measured with the automated Access platform (Triage BNP reagents, Access Immunoassay Systems, REF 98200, Beckman Coulter, Inc., Fullerton, CA 92835). The trend was indicated by a continuous line, assessed by smooth spline analysis (data modified from references [19, 32, 33] )

of various etiologies, including 14 cases of dilated cardiomyopathy, NT-proBNP levels were significantly higher than in controls and showed correlation with the ejection fraction and with the clinical heart failure (HF) score [53]. Children with dilated cardiomyopathy appeared to have higher BNP values than those with hypertrophic and restrictive forms [53]. BNP and NT-proBNP may be helpful in detecting latent left ventricular impairment in children with doxorubicin-induced cardiomyopathy [5459] as well as in those with iron-overload cardiomyopathy in beta thalassemia major [58].

\section{BNP as a diagnostic tool}

Data discussed in the previous paragraphs clearly indicate that reliable age-related pediatric reference values for BNP/ NT-proBNP are available, and natriuretic peptides correlate with various indexes of disease severity in children with congenital and acquired heart defects. In the following section, another relevant question that is whether BNP may be helpful for the diagnosis of heart failure of various etiologies will be discussed.

According to the Evidence-Based Laboratory Medicine (EBLM) principles, the development of a medical test like the BNP assay is a multiphase process [63]: The first phase includes the evaluation of the analytical performance of the test, as well as the set up of reference limits, whereas the remaining phases concern the efficacy and efficiency of the biomarker as a clinical laboratory test. The clinical impact of BNP/NT-proBNP assay has been tested through four prospective studies with control groups. Aiming to diagnose an at-risk population, these selected studies differ from other studies that identify an association of hemodynamical significant heart disease with a BNP increases. The study by Koulouri et al. [64], in acute care setting, enrolled 49 children with acute respiratory distress; of these, 29 turned out to have HF. A BNP of $40 \mathrm{pg} / \mathrm{mL}$ produced a sensitivity of $91 \%$ and specificity of $77 \%$. However, the study had also included patients who had an acknowledged condition of heart disease prior to presentation. Another study with similar design again allowed enrollment of patients with known heart disease of which 17 with heart failure, 18 with lung disease, and 13 healthy controls [65]. There was significant differentiation between the groups with the HF subgroup having a NTproBNP of $26,344 \mathrm{pg} / \mathrm{mL}$ and lung disease of $458 \mathrm{pg} / \mathrm{mL}$. A prospective study by Maher et al. [148] considered 2 groups of sick children, a critically sick cohort with heart disease and less compromised cohort comprising patients presenting at the emergency department for respiratory distress or infection and found BNP to be higher in the first group. The 33 patients with newly discovered heart disease had were $3290 \mathrm{pg} / \mathrm{mL}$ vs. $17.4 \mathrm{pg} / \mathrm{mL}$ for the 70 sick subjects in the comparison group.

To date, the most rigorous study done to date in pediatrics enrolled all-comers who were equally sick presenting to the acute care setting where the front-line physician queried whether hemodynamically significant cardiovascular disease was present [66]. Clinicians were not aware on patient's history of heart disease and were blinded to the BNP result and relied on the cardiology consult alone as the official diagnosis. The study differentiated two cutoff values that best discriminated hemodynamically significant cardiovascular disease from other disease processes with a similar presentation. For neonates 0-7 days of age $(n=42)$, a cutoff of $170 \mathrm{pg} / \mathrm{mL}$ produced a sensitivity of $94 \%$ and specificity of $73 \%$. For the older age group $(n=58)$, a cutoff of $41 \mathrm{pg} / \mathrm{mL}$ produced a sensitivity of $87 \%$ and specificity of $70 \%$. Nonetheless, the study presented a great limitation as to sample size and heterogeneity of age groups.

Generally speaking higher accuracy measures, for example, may be attained if multiple cutoffs are determined by age group, especially during the early infancy when BNP and NT-proBNP decrease over the first few months of life-which could explain why BNP underperforms compared to accuracy values reported in studies of adults with possible HF or ventricular dysfunction ([67], see Table 2). 


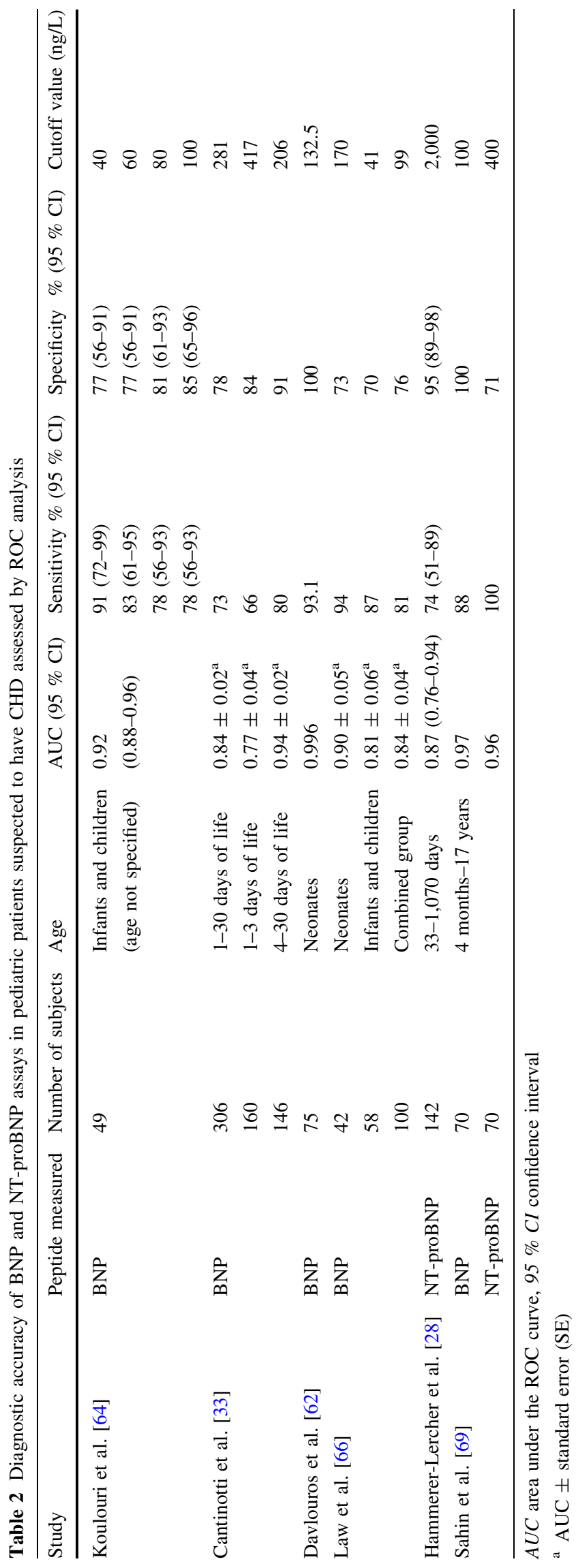

\section{BNP in the assessment of heart failure}

In addition to the prospective studies aimed at diagnosing new HF mentioned in the previous section, numerous other studies have been performed to make the correlation between BNP and various forms of heart disease in children. For example, several pediatric studies made the association of HF with increased BNP using healthy children as a comparative group in their analysis [66-72]. Attempts from retrospective and prospective studies have also determined BNP's diagnostic accuracy, of which some are lesion specific (Table 2).

Data reported in Tables 3 and 4 indicate that on average BNP/NT-proBNP immunoassay methods share a good (or even very good in some studies) clinical accuracy in the diagnosis of heart failure in children with CHD, showing AUC values from 0.77 to 0.97 (on average approximately 0.88 ) using the ROC curve analysis.

Overall, studies demonstrate there is a correlation with the severity of heart failure in most cases $[52,53,69,70$, 73] with few exceptions [71, 74, 75]. In particular, there appears to be an association between BNP levels and NYHA functional class in adults with systemic morphological right ventricle [76-88], as well as in patients with transposition of the great arteries after atrial switch operation (Mustard or Senning) and congenitally corrected transposition of the great arteries [79, 81, 85]. BNP values, however, were higher than controls even when no signs or symptoms of HF were present.

Significant correlations between BNP levels and right ventricular (RV) function [76, 77, 80, 84, 85], end-diastolic volume [77, 78, 81, 86], and severity of tricuspid valve regurgitation [79, 87] measured by either cardiac magnetic resonance or echocardiography were also observed. Furthermore, plasma BNP correlated negatively with peak oxygen consumption [78-80, 84, 86].

BNP may also be employed in the management of children with univentricular heart [46, 47, 87-107]. Despite data being still controversial in this patient setting, a recent study involving a cohort of 510 children (6-18 years old at a median of 8.2 years after Fontan) found BNP to be variable but within a normal range in the majority of patients and only weakly correlated with clinical and functional status [91].

Some studies suggest that plasma BNP and NT-proBNP may be employed as adjunctive tests for the diagnosis of HF in children with single-ventricle (SV) physiology [89, 90, 149]. Other studies have shown Fontan patients with a better functional capacity to have lower values compared to those with a lower level of functional capacity using either the New York Heart Association (NYHA) or the New York University Pediatric Heart Failure Score [48, 92, 96, 103]. 


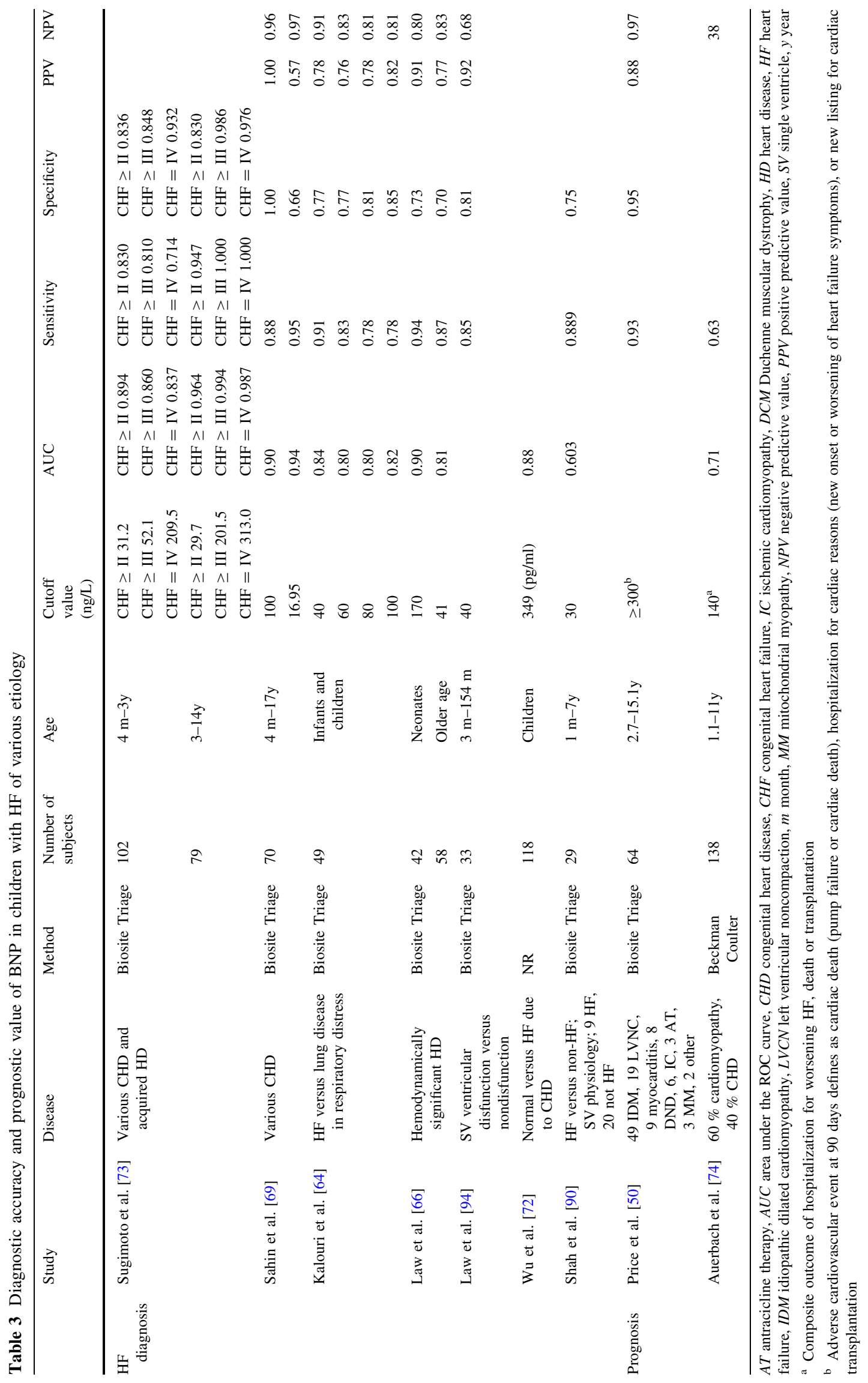


It has also been demonstrated that in the setting of SV circulation, raised BNP values may help to distinguish HF due to ventricular dysfunction from isolated cavo-pulmonary failure [94] since the synthesis of BNP resides within the ventricle not the venous-pulmonary artery circulation.

Perhaps also related to the source of production of the peptide, BNP has been shown to be higher in classic Fontan patients compared with total cavo-pulmonary connection patients [91, 96, 97].

A decrease in BNP through various stages of palliation has also been demonstrated [49, 94], and in asymptomatic children and adolescents after completion of the Fontan procedure, average BNP values were comparable to healthy age-matched controls [49, 91, 94, 96, 99, 101, 103]. Furthermore, adolescents with Fontan circulation and HF showed NT-proBNP values significantly higher than those with Fontan without HF, and natriuretic peptides values correlate with the severity of cardiac failure [103]. Moreover, adult patients with Fontan showed higher BNP values compared to those with other corrected/palliated CHD [107]. It is noteworthy to mention that BNP correlated with several echocardiographic parameters including the severity of atrio-ventricular valve regurgitation [48], systolic ventricular function [107], indices of diastolic function [99], and total ventricular mass by magnetic resonance imaging [91].

Data on the correlation between BNP and peak oxygen consumption and chronotropic index during exercise testing are conflicting $[49,92]$ with only a few studies showing significant correlations [7,96]. Data on the prognostic utility of BNP in the follow-up of patients with univentricular heart are also inconclusive [89, 91]. In some studies, higher BNP values seem to be associated with poor outcome [48] and worse neurodevelopmental outcomes in infants with single-ventricle physiology [106], although data are limited and inconclusive [91, 101].

BNP has gained usage in the follow-up of patients after tetralogy of Fallot repair with the typical sequelae, i.e., residual pulmonary regurgitation and/or stenosis [2, 3, 108-125]. In the integrated follow-up of tetralogy of Fallot patients, it is important to note that right ventricular dilatation is not necessarily accompanied by a deterioration of cardiac function; indeed, in some patients, symptoms may be mild or completely absent and decision between an interventional or conservative approach is often controversial $[2,5,7]$. In this setting, the use of BNP may help provide important additional information.

In patients awaiting valvular replacement, BNP was higher in NYHA class II compared to NYHA-I [111-114] and correlated negatively with exercise time and positively with right ventricular dilatation and both tricuspid and pulmonary regurgitation. A significant reduction in BNP 
values after valve replacement has also been well documented $[2,5,7,105,111,115]$. In the majority of studies, BNP correlates with degree of pulmonary regurgitation, and right ventricle end-diastolic volume and systolic pressure [112-114, 119-121, 123]. In contrast, correlation between BNP and RV function was discordant among various studies [7, 112-114, 119-121, 123]. It is important to remark that the increase in BNP in tetralogy of Fallot patients may be related not only to right ventricular dysfunction but also to the involvement of left ventricle [112]. The response of cardiac endocrine function (as indicated by the measurement of plasma BNP) to stress test in patients after surgical repair of tetralogy of Fallot was more pronounced compared to normal subjects [71, 106, 110, 113]. Furthermore, significant correlations were found between BNP and cardiopulmonary parameters during stress test including peak oxygen uptake, forced vital capacity, and the minute ventilation/carbon dioxide production ratio.

\section{BNP in monitoring response to therapy and prognosis}

The utility of BNP as a prognostic marker has been tested in various cardiomyopathies including dilated [50, 53], left ventricular non-compaction [50], inflammatory [50], dystrophin [50], ischemic [50], oncologic [50, 56-58], and mitochondrial [66]. In particular, BNP values $<300 \mathrm{pg} / \mathrm{ml}$ have shown to have accuracy values of sensitivity 0.93 , specificity 0.95 , positive predictive value 0.88 , and negative predictive value 0.97 for the prediction of adverse cardiovascular events in pediatric outpatients with chronic left ventricular dysfunction due to various cardiomyopathies [50]. A post hoc analysis of the pediatric carvedilol trial included a larger group of subjects with congenital heart disease with a broader age range [74]. Similar adverse event end points of heart failure admission, death, and transplantation were chosen. The authors found a BNP cutoff of $140 \mathrm{ng} / \mathrm{L}$ to be the most accurate for risk stratification considering a composite end point (including hospitalization for worsening HF, all-cause mortality and cardiac transplantation) with a sensitivity of $71 \%$ and specificity of $63 \%$ [74]. Controlling for other clinical factors, this cutoff was associated with death and transplantation for children above 2 years of age.

In a study involving 24 children (median age 8.7 years) with acute HF (including 17 with cardiomyopathy of various types), NT-proBNP decreased in those patients who did not required mechanical circulatory support (MCS), but not in those who were eventually placed on MCS [75]. It is important to note that a single time point (value) in NTproBNP did not predict the need for MCS.

In a group of 41 children with cardiac failure (due to cardiac or pulmonary disease), NT-proBNP values were higher in those who died than in survivors, who instead experienced a significant decrease after treatment [124].

In a study evaluating serum and echocardiographic predictors of death and need for transplant conducted over 91 children (median age 3 years; range $0-18$ ) with HF for various $\mathrm{CHD}$, the adjunct of BNP in 51 patients did not improve the model's accuracy markedly [125].

Some recent studies suggest that BNP is a reliable prognostic biomarker in congenital heart disease surgery [126$145,150]$. In particular, these studies indicate that BNP levels (especially those measured preoperatively) are independently associated with the duration of mechanical ventilation, intensive care unit stay, need for inotropic support, and low cardiac output syndrome [126-138]. As may be expected from the foregoing sections, the postoperative use of natriuretic peptides is complicated by the heterogeneity of cardiac lesions and the age groups of patients, namely the change in BNP after pediatric cardiac surgery seems to be age and disease dependent [2, 7, 135-137]. As a group, neonates showed an opposite response to those observed in older children. Studies by Cantinotti et al. showed that BNP values tended to increase after corrective neonatal surgery while decreased in the older age patients [136, 137, 144].

This may be partly explained by the severity of disease and complexity of procedures undertaken in neonates. However, when complexity is adjusted with the Aristotle and RACHS classification, the only parameter affecting postoperative BNP levels is age. It is also apparent that natriuretic peptide levels reach peak levels at approximately $12 \mathrm{~h}$ after the separation from cardiopulmonary bypass [126, 127, 129, 134]. Further increases after that time can imply potential problems ahead. When compared to other bedside monitoring such as vital signs and lactate, BNP remained significant in its association with an adverse outcome when patients were subclassified by type of lesion [135]. In another large study, incorporating a comparison group of noncardiac patients undergoing similarly long noncardiac surgery, Niedner et al. [133] demonstrated BNP to correlate with the intensity of postoperative support. In smaller studies that focused on specific patient groups, natriuretic peptide in general showed positive correlation with a complicated postoperative course and composite outcome measures. Hsu et al. examined 36 consecutive neonates undergoing various repairs and showed the 24-h to preoperative BNP ratio to be predictive of an adverse outcome that included death [127]. Another study examined neonates who had the arterial switch procedure and showed BNP was associated with low cardiac output state and length of mechanical ventilation [130]. Several studies focused on the single-ventricle population as well. There was an association of 6-12 h BNP levels with more complicated clinical course after the cavo-pulmonary connection $[126,127]$. The one study that is an outlier found 
troponin and lactate, but not NT-proBNP, to have a better correlation with the need for more intensive support in a diverse group of 23 patients [131].

Lastly, with the introduction of mechanical circulatory assistance in children, a study by Heise et al. [143] showed NT-proBNP and BNP to decrease significantly after implantation of the Berlin EXCOR, substantiating the advantageous neurohormone response when the ventricle is unloaded; however, given the complexity of the clinical course in this small group of patients, association with outcome was not demonstrated.

The use of BNP to monitor and predict postoperative circulatory recovery is not conclusive. Despite there being a trend for higher natriuretic peptides in those who require more intensive support, research must still confirm under which conditions that occurs (which natriuretic peptide level time point, under which cardio-surgical condition) and whether it adds to conventional indicators (echocardiography, modern intensive care unit bedside monitoring, and direct physician assessment of acute and irrecoverable cardiac dysfunction).

\section{Summary}

The practice of cardiology is in continual evolution, alongside medical research progresses in understanding the pathophysiology of cardiovascular disease and in developing new therapeutic procedures [146]. Consequently, developers of cardiac biomarkers are pressed with new demands to improve the performance of the existing and the development of novel ones. However, the implementation of a novel biomarker in clinical practice according to Evidence-Based Medicine principle is a longstanding and costly process [147].

After more than 30 years of continuous studies [1], the measurement of circulating BNP and NT-proBNP is now recommended by international guidelines $[3,4]$ as a biomarker for diagnosis, prognosis, and therapeutic monitoring in adult patients with cardiac diseases. Unfortunately, there are fewer data of BNP/NT-proBNP in the pediatric population.

So far, the data available today can however support the use of BNP/NT-proBNP in specific cases:

1. For the integrated evaluation and monitoring of children with known heart disease, to allow the further defining of severity and progression of heart failure, and its response to therapy;

2. As an adjunctive marker, not a stand-alone test, in the screening of hemodynamically significant cardiovascular disease as well as in the prognosis of children undergoing cardiac surgery.
It must be said however that these indications are based on texts generally conducted on limited populations, singlerandomized or nonrandomized trials. As a result, they may theoretically achieve a level II B according to current classification of recommendations and level of evidence [3].

Thus further prospective studies are needed to demonstrate the true benefit of the BNP/NT-proBNP assay in these various aspects in the management of children with heart disease.

Conflict of interest None declared for MC and AC. YL has research support from Alere inc.

\section{References}

1. Clerico A, Giannoni A, Vittorini S, Passino C (2011) Thirty years of the heart as an endocrine organ: physiological role and clinical utility of cardiac natriuretic hormones. Am J Physiol Heart Circ Physiol 301:H12-H20

2. Cantinotti M, Giovannini S, Murzi B, Clerico A (2011) Review: Diagnostic, prognostic and therapeutic relevance of B-type natriuretic peptide assay in children with congenital heart diseases. Clin Chem Lab Med 49:567-580

3. Thygesen K, Mair J, Mueller C, Huber K, Weber M, Plebani M, Hasin Y, Biasucci LM, Giannitsis E, Lindahl B, Koenig W, Tubaro M, Collinson P, Katus H, Galvani M, Venge P, Alpert JS, Hamm C, Jaffe AS (2012) Recommendations for the use of natriuretic peptides in acute cardiac care. A position statement from the Study Group on Biomarkers in Cardiology of the ESC Working Group on Acute Cardiac Care. Eur Heart J 33: 2001-2006

4. NICE Clinical Guideline No 108 (2010) Chronic heart failure: National clinical guideline for diagnosis and management in primary and secondary care. pp 1-222

5. Eindhoven JA, van den Bosch AE, Jansen PR, Boersma E, Roos-Hesselink JW (2012) The usefulness of brain natriuretic peptide in complex congenital heart disease: a systematic review. J Am Coll Cardiol 60:2140-2149

6. Clerico A, Carlo Zucchelli G, Pilo A, Passino C, Emdin M (2006) Clinical relevance of biological variation: the lesson of brain natriuretic peptide (BNP) and NT-proBNP assay. Clin Chem Lab Med 44:366-378

7. Cantinotti M, Clerico A, Murzi M, Vittorini S, Emdin M (2008) Clinical relevance of measurement of brain natriuretic peptide and $\mathrm{N}$-terminal pro-brain natriuretic peptide in paediatric cardiology. Clin Chim Acta 390:12-22

8. Nir A, Lindinger A, Rauh M, Bar-Oz B, Laer S, Schwachtgen L et al (2009) NT-Pro-B-type natriuretic peptide in infants and children: reference values based on combined data from four studies. Pediatr Cardiol 30:3-8

9. Mir TS, Flato M, Falkenberg J, Haddad M, Budden R, Weil J (2006) Plasma concentrations of N-terminal brain natriuretic peptide in healthy children, adolescents, and young adults: effect of age and gender. Pediatr Cardiol 27:73-77

10. Mansoub S, Chan MK, Adeli K (2006) Gap analysis of pediatric reference intervals for risk biomarkers of cardiovascular disease and the metabolic syndrome. Clin Biochem 39:569-587

11. Koch A, Singer M (2003) Normal values of B type natriuretic peptide in infants, children, and adolescents. Heart 89:875-878

12. Mir TS, Laux R, Hellwege HH, Liedke B, Heinze C, von Buelow $\mathrm{H}$ et al (2003) Plasma concentrations of aminoterminal 
pro atrial natriuretic peptide and aminoterminal pro brain natriuretic peptide in healthy neonates: marked and rapid increase after birth. Pediatrics 112:896-899

13. Nir A, Bar-Oz B, Perles Z, Brooks R, Korach A, Rein AJ (2004) $\mathrm{N}$-terminal pro-B-type natriuretic peptide: reference plasma levels from birth to adolescence. Elevated levels at birth and in infants and children with heart diseases. Acta Paediatr 93:603-607

14. Kunii Y, Kamada M, Ohtsuki S, Araki T, Kataoka K, Kageyama M (2003) Plasma brain natriuretic peptide and the evaluation of volume overload in infants and children with congenital heart disease. Acta Med Okayama 57:191-197

15. Rauh M, Koch A (2003) Plasma N-terminal pro-B-type natriuretic peptide concentrations in a control population of infants and children. Clin Chem 49:1563-1564

16. Schwachtgen L, Herrmann M, Georg T, Schwarz P, Marx N, Lindinger A (2005) Reference values of NT-proBNP serum concentrations in the umbilical cord blood and in healthy neonates and children. Z Kardiol 94:399-404

17. Albers S, Mir TS, Haddad M, Läer S (2006) N-Terminal probrain natriuretic peptide: normal ranges in the pediatric population including method comparison and inter-laboratory variability. Clin Chem Lab Med 44:80-85

18. Cohen S, Springer C, Avital A, Perles Z, Rein AJ, Argaman Z et al (2005) Amino-terminal pro-brain-type natriuretic peptide: heart or lung disease in pediatric respiratory distress? Pediatrics 115:1347-1350

19. Cantinotti M, Storti S, Parri MS, Murzi M, Clerico A (2009) Reference values for plasma B-type natriuretic peptide in the first days of life. Clin Chem 55:1438-1440

20. Soldin SJ, Soldin OP, Boyajian AJ, Taskier MS (2006) Pediatric brain natriuretic peptide and $\mathrm{N}$-terminal pro-brain natriuretic peptide reference intervals. Clin Chim Acta 366:304-308

21. Maffei S, Del Ry S, Prontera C, Clerico A (2001) Increase in circulating levels of cardiac natriuretic peptides after hormone replacement therapy in postmenopausal women. Clin Sci 101: $447-453$

22. Hammerer-Lercher A, Mair J, Tews G, Puschendorf B, Sommer R (2005) N-terminal pro-B-type natriuretic peptide concentrations are markedly higher in the umbilical cord blood of newborns than in their mothers. Clin Chem 51:913-915

23. Bakker J, Gies I, Slavenburg B, Bekers O, Delhaas T, van Dieijen-Visser M (2004) Reference values for N-terminal pro-Btype natriuretic peptide in umbilical cord blood. Clin Chem 50: 2465

24. Bar-Oz B, Lev-Sagie A, Arad I, Salpeter L, Nir A (2005) $\mathrm{N}$-terminal pro-B-type natriuretic peptide concentrations in mothers just before delivery, in cord blood, and in newborns. Clin Chem 51:926-927

25. Mannarino S, Ciardelli L, Garofoli F, Perotti G, Mongini E, Damiano S et al (2009) Correlation between cord blood, perinatal BNP values and echocardiographic parameters in healthy Italian newborns. Early Hum Dev 85:13-17

26. Mannarino S, Garofoli F, Cerbo RM, Perotti G, Mongini E, Codazzi C et al (2010) Cord blood, perinatal BNP values in term and preterm newborns. Arch Dis Child Fetal Neonatal Ed 95:F74

27. Mannarino S, Garofoli F, Mongini E, Cerbo RM, Codazzi AC, Tzialla C et al (2010) BNP concentrations and cardiovascular adaptation in preterm and full-term newborn infants. Early Hum Dev 86:295-298

28. Hammerer-Lercher A, Puschendorf B, Sommer R, Mair J, Tews G, Shebl O et al (2007) Natriuretic peptides correlate between newborn twins but not between twins and their mothers. Clin Chim Acta 377:279-280

29. Halse KG, Lindegaard ML, Goetze JP, Damm P, Mathiesen ER, Nielsen LB (2005) Increased plasma pro-B-type natriuretic peptide in infants of women with type 1 diabetes. Clin Chem 51:2296-2302

30. Nybo M, Nielsen LB, Nielsen SJ, Lindegaard M, Damm P, Rehfeld JF et al (2007) Discordant expression of pro-B-type and pro- C-type natriuretic peptide in newborn infants of mothers with type 1 diabetes. Regul Pept 41:135-139

31. Kanbe T, Maeno Y, Fujino H, Kanda H, Hirose A, Okada J et al (2009) Brain-type natriuretic peptide at birth reflects fetal maturation and antenatal stress. Acta Paediatr 98:1421-1425

32. Cantinotti M, Storti S, Parri MS, Prontera C, Murzi B, Clerico A (2010) Reference intervals for brain natriuretic peptide in healthy newborns and infants measured with an automated immunoassay platform. Clin Chem Lab Med 48:697-700

33. Cantinotti M, Storti S, Ripoli A, Zyw L, Crocetti M, Assanta N et al (2010) Diagnostic accuracy of B-type natriuretic hormone for congenital heart disease in the first month of life. Clin Chem Lab Med 48:1333-1338

34. Clerico A, Passino C, Emdin M (2011) When gonads talk to the heart sex hormones and cardiac endocrine function. J Am Coll Cardiol 58:627-628

35. Prontera C, Zaninotto M, Giovannini S, Zucchelli GC, Pilo A, Sciacovelli L et al (2009) Proficiency testing project for brain natriuretic peptide (BNP) and the N-terminal part of the propeptide of BNP (NT-proBNP) immunoassays: the CardioOrmoCheck study. Clin Chem Lab Med 47:762-768

36. Clerico A, Zaninotto M, Prontera C, Giovannini S, Ndreu R, Franzini M et al (2012) State of the art of BNP and NT-proBNP immunoassays: the CardioOrmoCheck study. Clin Chim Acta 414:112-119

37. Holmgren D, Westerlind A, Lundberg PA, Wahlander H (2005) Increased plasma levels of natriuretic peptide type B and A in children with congenital heart defects with left compared with right ventricular volume overload or pressure overload. Clin Physiol Funct Imaging 25:263-269

38. Koch A, Zink S, Singer H (2006) B-type natriuretic peptide in paediatric patients with congenital heart disease. Eur Heart $\mathbf{J}$ 27:861-866

39. Cowley CG, Bradley JD, Shaddy RE (2004) B-type natriuretic peptide levels in congenital heart disease. Pediatr Cardiol 25:336-340

40. Kunii Y, Kamada M, Ohtsuki S, Araki T, Kataoka K, Kageyama M (2003) Plasma brain natriuretic peptide and the evaluation of volume overload in infants and children with congenital heart disease. Acta Med Okayama 57:191-197

41. Lin NC, Landt ML, Trinkaus KM, Balzer DT, Kort HW, Canter CE (2005) Relation of age, severity of illness, and hemodynamics with brain natriuretic peptide levels in patients -20 years of age with heart disease. Am J Cardiol 96:847-850

42. Czernik C, Lemmer J, Metze B, Koehne PS, Mueller C, Obladen M (2008) B-type natriuretic peptide to predict ductus intervention in infants -28 weeks. Pediatr Res 64:286-290

43. Farombi-Oghuvbu I, Matthews T, Mayne PD, Guerin H, Corcoran JD (2008) N-terminal pro-B-type natriuretic peptide: a measure of significant patent ductus arteriosus. Arch Dis Child Fetal Neonatal Ed 93:F257-F260

44. Eerola A, Jokinen E, Boldt T, Pihkala J (2006) The influence of percutaneous closure of patent ductus arteriosus on left ventricular size and function: a prospective study using two- and three dimensional echocardiography and measurements of serum natriuretic peptides. J Am Coll Cardiol 47:1060-1066

45. Flynn PA, da Graca RL, Auld PA, Nesin M, Kleinman CS (2005) The use of a bedside assay for plasma B-type natriuretic peptide as a biomarker in the management of patent ductus arteriosus in premature neonates. J Pediatr 147:38-42

46. Tosse V, Pillekamp F, Verde P, Hadzik B, Sabir H, Mayatepek E, Hoehn T (2012) Urinary NT-proBNP, NGAL, and H-FABP 
may predict hemodynamic relevance of patent ductus arteriosus in very low birth weight infants. Neonatology 101:260-266

47. Kalra VK, DeBari VA, Zauk A, Kataria P, Myridakis D, Kiblawi F (2011) Point-of-care testing for B-type natriuretic peptide in premature neonates with patent ductus arteriosus. Ann Clin Lab Sci 41:131-137

48. Koch A, Zink S, Singer H, Dittrich S (2008) B-type natriuretic peptide levels in patients with functionally univentricular hearts after total cavo-pulmonary connection. Eur J Heart Fail 10: $60-62$

49. Holmgren D, Westerlind A, Berggren H, Lundberg PA, Wahlander $H$ (2008) Increased natriuretic peptide type B level after the second palliative step in children with univentricular hearts with right ventricular morphology but not left ventricular morphology. Pediatr Cardiol 29:786-792

50. Price JF, Thomas AK, Grenier M, Eidem BW, O'Brian Smith E, Denfield SW et al (2006) B-type natriuretic peptide predicts adverse cardiovascular events in pediatric outpatients with chronic left ventricular systolic dysfunction. Circulation 114: 1063-1069

51. Kaski JP, Tomé-Esteban MT, Mead-Regan S, Pantazis A, Marek J, Deanfield JE, McKenna WJ, Elliott PM (2008) B-type natriuretic peptide predicts disease severity in children with hypertrophic cardiomyopathy. Heart 94:1307-1311

52. Sangeev S, Pettersen M, Lua J, Thomas R, Shankaran S, L'Ecuyer T (2005) Role of plasma B-type natriuretic peptide in screening for hemodynamically significant patent ductus arteriosus in preterm neonates. J Perinatol 25:709-713

53. Mir TS, Marohn S, Läer S, Eiselt M, Grollmus O, Weil J (2002) Plasma concentrations of N-terminal pro-brain natriuretic peptide in control children from the neonatal to adolescent period and in children with congestive heart failure. Pediatrics 110:e76

54. Häusermann E, Fasnacht M, Hersberger M, Gessler P, Bauersfeld U (2011) Plasma B-type natriuretic peptide levels in children with heart disease. Acta Paediatr 100:1213-1216

55. Hongkan W, Soongswang J, Veerakul G, Sanpakit K, Punlee K, Rochanasiri W, Udompunturak S (2009) N-terminal pro brain natriuretic peptide and cardiac function in doxorubicin administered pediatric patients. J Med Assoc Thai 92:1450-1457

56. Kervancioglu M (2005) Plasma concentrations of NT-pro-BNP and cardiac troponin-I in relation to doxorubicin-induced cardiomyopathy and cardiac function in childhood malignancy. Saudi Med J 26:1197-1202

57. Komada Y, Hirayama M, Hori H, Ito M, Sakurai M (2001) Plasma levels of natriuretic peptides in relation to doxorubicininduced cardiotoxicity and cardiac function in children with cancer. Med Pediatr Oncol 37:4-9

58. Phil M, Khan DA, Tuyyab F (2012) Early detection of cardiac dysfunction by BNP in beta-thalassaemia major patients. Acta Cardiol 67:331-335

59. Aggarwal S, Pettersen MD, Bhambhani K, Gurczynski J, Thomas R, L'Ecuyer T (2007) B-type natriuretic peptide as a marker for cardiac dysfunction in anthracycline-treated children. Pediatr Blood Cancer 49:812-816

60. Saji T, Takatsuki S, Fujiwara M (2007) Abnormal tissue doppler images are associated with elevated plasma brain natriuretic peptide and increased oxidative stress in acute Kawasaki disease. Circ J 71:357-362

61. Ko HK, Lee JH, Choi BM, Lee JH, Yoo KH, Son CS et al (2008) Utility of the rapid B-type natriuretic peptide assay for detection of cardiovascular problems in newborn infants with respiratory difficulties. Neonatology 94:16-21

62. Davlouros PA, Karatza AA, Xanthopoulou I, Dimitriou G, Georgiopoulou A, Mantagos S et al (2011) Diagnostic role of plasma BNP levels in neonates with signs of congenital heart disease. Int J Cardiol 147:42-46
63. Emdin M, Vittorini S, Clerico A, Passino C (2009) Old and new biomarkers of heart failure. Eur J Heart Fail 11:331-335

64. Koulouri S, Acherman RJ, Wong PC, Chan LS, Lewis AB (2004) Utility of B-type natriuretic peptide in differentiating congestive heart failure from lung disease in pediatric patients with respiratory distress. Pediatr Cardiol 25:341-346

65. Cohen S, Springer C, Avital A, Perles Z, Rein AJ, Argaman Z et al (2005) Amino-terminal pro-brain-type natriuretic peptide: heart or lung disease in pediatric respiratory distress? Pediatrics 115:1347-1350

66. Law YM, Hoyer AW, Reller MD, Silberbach M (2009) Accuracy of plasma B-type natriuretic peptide to diagnose significant cardiovascular disease in children: the Better Not Pout Children! Study. J Am Coll Cardiol 54:1467-1475

67. Maisel A, Mueller C (2008) North American B-type natriuretic peptide (BNP) consensus working group. Congest Heart Fail 14(4 Suppl 1):4

68. Cantinotti M, Clerico A, Murzi M, Vittorini S, Emdin M (2008) Clinical relevance of measurement of brain natriuretic peptide and N-terminal pro-brain natriuretic peptide in pediatric cardiology. Clin Chim Acta 390:12-22

69. Sahin M, Portakal O, Karagöz T, Haşcelik G, Ozkutlu S (2010) Diagnostic performance of BNP and NT-ProBNP measurements in children with heart failure based on congenital heart defects and cardiomyopathies. Clin Biochem 43:1278-1281

70. Nishiyama M, Park IS, Yoshikawa T, Hatai Y, Ando M, Takahashi Y, Mori K, Murakami Y (2009) Efficacy and safety of carvedilol for heart failure in children and patients with congenital heart disease. Heart Vessels 24:187-192

71. Trojnarska O, Gwizdala A, Katarzyński S, Katarzyńska A, Szyszka A, Lanocha M et al (2009) Evaluation of exercise capacity with cardiopulmonary exercise test and B-type natriuretic peptide in adults with congenital heart disease. Cardiol J 16:133-141

72. Wu YR, Chen SB, Sun K, Huang MR, Zhang YQ, Chen S (2006) Diagnostic value of the currently used criteria and brain natriuretic peptide for diagnosing congestive heart failure in children with congenital heart disease. Zhonghua Er Ke Za Zhi 44:728-732

73. Sugimoto M, Manabe H, Nakau K, Furuya A, Okushima K, Fujiyasu H, Kakuya F, Goh K, Fujieda K, Kajino H (2010) The role of N-terminal pro-B-type natriuretic peptide in the diagnosis of congestive heart failure in children. Circ J 74:998-1005

74. Auerbach SR, Richmond ME, Lamour JM, Blume ED, Addonizio LJ, Shaddy RE, Mahony L, Pahl E, Hsu DT (2010) BNP levels predict outcome in pediatric heart failure patients: post hoc analysis of the pediatric carvedilol trial. Circ Heart Fail 3:606-611

75. Wong DT, George K, Wilson J, Manlhiot C, McCrindle BW, Adeli K, Kantor PF (2011) Effectiveness of serial increases in amino-terminal pro-B-type natriuretic peptide levels to indicate the need for mechanical circulatory support in children with acute decompensated heart failure. Am J Cardiol 107:573-578

76. Chow PC, Cheung EW, Chong CY et al (2008) Brain natriuretic peptide as a biomarker of systemic right ventricular function in patients with transposition of great arteries after atrial switch operation. Int J Cardiol 127:192-197

77. Schaefer A, Tallone EM, Westhoff-Bleck M, Klein G, Drexler H, Rontgen P (2010) Relation of diastolic and systolic function, exercise capacity and brain natriuretic peptide in adults after Mustard procedure for transposition of the great arteries. Cardiology 117:112-117

78. Larsson DA, Meurling CJ, Holmqvist F, Waktare JE, Thilen UJ (2007) The diagnostic and prognostic value of brain natriuretic peptides in adults with a systemic morphologically right ventricle or Fontan-type circulation. Int J Cardiol 114:345-351 
79. Koch AM, Zink S, Singer H (2008) B-type natriuretic peptide in patients with systemic right ventricle. Cardiology 110:1-7

80. Garg R, Raman SV, Hoffman TM, Hayes J, Daniels CJ (2008) Serum markers of systemic right ventricular function and exercise performance. Pediatr Cardiol 29:641-648

81. Plymen CM, Hughes ML, Picaut N et al (2010) The relationship of systemic right ventricular function to ECG parameters and NtproBNP levels in adults with transposition of the great arteries late after Senning or Mustard surgery. Heart 96:1569-1573

82. Neffke JG, Tulevski II, van der Wall EE et al (2002) ECG determinants in adult patients with chronic right ventricular pressure overload caused by congenital heart disease: relation with plasma neurohormones and MRI parameters. Heart 88: 266-270

83. Winter MM, Bouma BJ, van Dijk AP et al (2008) Relation of physical activity, cardiac function, exercise capacity, and quality of life in patients with a systemic right ventricle. Am J Cardiol 102:1258-1262

84. Norozi K, Buchhorn R, Alpers V et al (2005) Relation of systemic ventricular function quantified by myocardial performance index (Tei) to cardiopulmonary exercise capacity in adults after Mustard procedure for transposition of the great arteries. Am J Cardiol 96:1721-1725

85. Kozelj M, Prokselj K, Berden P et al (2008) The syndrome of cardiac failure in adults with congenitally corrected transposition. Cardiol Young 18:599-607

86. Dore A, Houde C, Chan KL et al (2005) Angiotensin receptor blockade and exercise capacity in adults with systemic right ventricles: a multicenter, randomized, placebo-controlled clinical trial. Circulation 112:2411-2416

87. Vogt M, Kuhn A, Wiese J, Eicken A, Hess J, Vogel M (2009) Reduced contractile reserve of the systemic right ventricle under dobutamine stress is associated with increased brain natriuretic peptide levels in patients with complete transposition after atrial repair. Eur J Echocardiogr 10:691-694

88. Szymanski P, Klisiewicz A, Lubiszewska B et al (2010) Functional anatomy of tricuspid regurgitation in patients with systemic right ventricles. J Am Soc Echocardiogr 23:504-510

89. Lowenthal A, Camacho BV, Lowenthal S, Natal-Hernandez L, Liszewski W, Hills NK, Fineman JR, Bernstein HS (2012) Usefulness of B-type natriuretic peptide and N-terminal pro-Btype natriuretic peptide as biomarkers for heart failure in young children with single ventricle congenital heart disease. Am J Cardiol 109:866-872

90. Shah A, Feraco AM, Harmon C, Tacy T, Fineman JR, Bernstein HS (2009) Usefulness of various plasma biomarkers for diagnosis of heart failure in children with single ventricle physiology. Am J Cardiol 104:1280-1284

91. Atz AM, Zak V, Breitbart RE, Colan SD, Pasquali SK, Hsu DT, Lu M, Mahony L, Paridon SM, Puchalski MD, Geva T, McCrindle BW, Pediatric Heart Network Investigators (2011) Factors associated with serum brain natriuretic peptide levels after the Fontan procedure. Congenit Heart Dis 6:313-321

92. Lechner E, Schreier-Lechner EM, Hofer A, Gitter R, Mair R, Biebl A et al (2009) Amino-terminal brain-type natriuretic peptide levels correlate with heart failure in patients with bidirectional Glenn anastomosis and with morbidity after the Fontan operation. J Thorac Cardiovasc Surg 138:560-564

93. Anderson PA, Sleeper LA, Mahony L, Colan SD, Atz AM, Breitbart RE et al (2008) Contemporary outcomes after the Fontan procedure: a Pediatric Heart Network multicenter study. J Am Coll Cardiol 52:114-116

94. Law YM, Ettedgui J, Beerman L, Maisel A, Tofovic S (2006) Comparison of plasma B-type natriuretic peptide levels in single ventricle patients with systemic ventricle heart failure versus isolated cavo-pulmonary failure. Am J Cardiol 98:520-524
95. Hsu JH, Oishi PE, Keller RL et al (2008) Perioperative B-type natriuretic peptide levels predict outcome after bidirectional cavo-pulmonary anastomosis and total cavo-pulmonary connection. J Thorac Cardiovasc Surg 135:746-753

96. Ohuchi $\mathrm{H}$, Takasugi $\mathrm{H}$, Ohashi $\mathrm{H}$ et al (2004) Abnormalities of neurohormonal and cardiac autonomic nervous activities relate poorly to functional status in Fontan patients. Circulation 110:2601-2608

97. Holmgren D, Stromvall-Larsson E, Lundberg PA, Eriksson BO, Wahlander $H$ (2007) Brain natriuretic peptide assessed at longterm follow-up before and after maximal exercise in surgically palliated patients with functionally univentricular hearts. Cardiol Young 17:505-511

98. Hjortdal VE, Stenbog EV, Ravn HB et al (2000) Neurohormonal activation late after cavo-pulmonary connection. Heart 83: 439-443

99. Man BL, Cheung YF (2007) Plasma brain natriuretic peptide and systemic ventricular function in asymptomatic patients late after the Fontan procedure. Heart Vessels 22:398-403

100. Robbers-Visser D, Kapusta L, van Osch-Gevers L et al (2009) Clinical outcome 5 to 18 years after the Fontan operation performed on children younger than 5 years. J Thorac Cardiovasc Surg 138:89-95

101. Inai K, Nakanishi T, Nakazawa M (2005) Clinical correlation and prognostic predictive value of neurohumoral factors in patients late after the Fontan operation. Am Heart J 150: $588-594$

102. Wahlander $\mathrm{H}$, Westerlind A, Lindstedt $\mathrm{G}$, Lundberg PA, Holmgren D (2003) Increased levels of brain and atrial natriuretic peptides after the first palliative operation, but not after a bidirectional Glenn anastomosis, in children with functionally univentricular hearts. Cardiol Young 13:268-274

103. Lechner E, Gitter R, Mair R et al (2008) Amino-terminal brain natriuretic peptide levels in children and adolescents after Fontan operation correlate with congestive heart failure. Pediatr Cardiol 29:901-905

104. Motoki N, Ohuchi H, Miyazaki A, Yamada O (2009) Clinical profiles of adult patients with single ventricular physiology. Circ J 73:1711-1716

105. Goldberg DJ, French B, McBride MG et al (2011) Impact of oral sildenafil on exercise performance in children and young adults after the Fontan operation: a randomized, double-blind, placebocontrolled, crossover trial. Circulation 123:1185-1193

106. Ravishankar C, Zak V, Williams IA, Bellinger DC, Gaynor JW, Ghanayem NS et al (2013) Association of impaired linear growth and worse neurodevelopmental outcome in infants with single ventricle physiology: a report from the pediatric heart network infant single ventricle trial. J Pediatr 162:250e2-256e2

107. Eindhoven JA, van den Bosch AE, Ruys TP, Opić P, Cuypers JA, McGhie JS, Witsenburg M, Boersma E, Roos-Hesselink JW (2013) N-Terminal Pro-B-Type natriuretic peptide and its relationship with cardiac function in adults with congenital heart disease. J Am Coll Cardiol 62:1203-1212

108. Apitz C, Sieverding L, Latus H, Uebing A, Schoof S, Hofbeck M (2009) Right ventricular dysfunction and B-type natriuretic peptide in asymptomatic patients after repair for tetralogy of Fallot. Pediatr Cardiol 30:898-904

109. Oosterhof T, Tulevski II, Vliegen HW, Spijkerboer AM, Mulder BJ (2006) Effects of volume and/or pressure overload secondary to congenital heart disease (tetralogy of Fallot or pulmonary stenosis) on right ventricular function using cardiovascular magnetic resonance and B-type natriuretic peptide levels. Am J Cardiol 97:1051-1055

110. Tulevski II, Groenink M, Van Der Wall FF, Van Velduisen DJ, Boomsma F, Stoker J (2001) Increased brain and atrial natriuretic peptides in patients with chronic right ventricular 
overload: correlation between plasma neuro-hormones and right ventricular dysfunction. Heart 86:27-30

111. Dodge-Khatami A, Büchel EV, Knirsch W, Kadner A, Rousson $\mathrm{V}$, Dave $\mathrm{HH}$ et al (2006) Brain natriuretic peptide and magnetic resonance imaging in tetralogy with right ventricular dilatation. Ann Thorac Surg 82:983-988

112. Norozi K, Buchhorn R, Bartmus D, Alpers V, Arnhold JO, Schoof S et al (2006) Elevated brain natriuretic peptide and reduced exercise capacity in adult patients operated on for tetralogy of Fallot is due to biventricular dysfunction as determined by the myocardial performance index. Am J Cardiol 97:1377-1382

113. Ishii H, Harada K, Toyono M, Tamura M, Takada G (2005) Usefulness of exercise-induces changes in plasma levels of brain natriuretic peptide in predicting right ventricular contractile reserve after repair of tetralogy of Fallot. Am J Cardiol 95: $1338-1343$

114. Cetin I, Tokel K, Varan B, Orun U, Aslamaci S (2009) Evaluation of right ventricular function by using tissue Doppler imaging in patients after repair of tetralogy of Fallot. Echocardiography 26:950-957

115. Knirsch W, Dodge-Khatami A, Kadner A et al (2008) Assessment of myocardial function in pediatric patients with operated tetralogy of Fallot: preliminary results with 2D strain echocardiography. Pediatr Cardiol 29:718-725

116. Koch AM, Zink S, Glockler M, Seeliger T, Dittrich S (2010) Plasma levels of B-type natriuretic peptide in patients with tetralogy of Fallot after surgical repair. Int J Cardiol 143: $130-134$

117. Festa P, Ait-Ali L, Prontera C et al (2007) Amino-terminal fragment of pro-brain natriuretic hormone identifies functional impairment and right ventricular overload in operated tetralogy of Fallot patients. Pediatr Cardiol 28:339-345

118. Brili S, Alexopoulos N, Latsios G et al (2005) Tissue Doppler imaging and brain natriuretic peptide levels in adults with repaired tetralogy of Fallot. J Am Soc Echocardiogr 18:1149-1154

119. Tatani SB, Carvalho AC, Andriolo A, Rabelo R, Campos O, Moises VA (2010) Echocardiographic parameters and brain natriuretic peptide in patients after surgical repair of tetralogy of Fallot. Echocardiography 27:442-447

120. Wand O, Perles Z, Rein AJ, Algur N, Nir A (2007) Clinical, echocardiographic and humoral status of patients following repair of tetralogy of Fallot: comparison of the second to the first decade. Isr Med Assoc J 9:843-846

121. Van den Berg J, Strengers JL, Wielopolski PA et al (2009) Assessment of biventricular functional reserve and NT-proBNP levels in patients with RV volume overload after repair of tetralogy of Fallot at young age. Int J Cardiol 133:364-370

122. Khositseth A, Manop J, Khowsathit P et al (2007) N-terminal pro-brain natriuretic peptide as a marker in follow-up patients with tetralogy of Fallot after total correction. Pediatr Cardiol 28:333-338

123. Norozi K, Bahlmann J, Raab B, Alpers V, Arnhold JO, Kuehne $\mathrm{T}$ et al (2007) A prospective, randomized, double-blind, placebo controlled trial of beta-blockade in patients who have undergone surgical correction of tetralogy of Fallot. Cardiol Young 17: 372-379

124. Roche SL, Grosse-Wortmann L, Redington AN et al (2010) Exercise induces biventricular mechanical dyssynchrony in children with repaired tetralogy of Fallot. Heart 96:2010-2015

125. Berry JG, Askovich B, Shaddy RE, Hawkins JA, Cowley CG (2008) Prognostic value of B-type natriuretic peptide in surgical palliation of children with single-ventricle congenital heart disease. Pediatr Cardiol 29:70-75

126. Hsu JH, Keller RL, Chikovani O, Cheng H, Hollander SA, Karl TR et al (2007) B-type natriuretic peptide levels predict outcome after neonatal cardiac surgery. J Thorac Cardiovasc Surg 134:939-944

127. Walsh R, Boyer C, LaCorte J, Parnell V, Sison C, Chowdhury D et al (2008) N-terminal B-type natriuretic peptide levels in pediatric patients with congestive heart failure undergoing cardiac surgery. J Thorac Cardiovasc Surg 135:98-105

128. Shih CY, Sapru A, Oishi P, Azakie A, Karl TR, Harmon C et al (2006) Alterations in plasma B-type natriuretic peptide levels after repair of congenital heart defects: a potential perioperative marker. J Thorac Cardiovasc Surg 131:632-638

129. Cannesson M, Bionda C, Gostoli B, Raisky O, di Filippo S, Bompard D et al (2007) Time course and prognostic value of plasma B-type natriuretic peptide concentration in neonates undergoing the arterial switch operation. Anesth Analg 104:1059-1065 (tables of contents)

130. Mir TS, Haun C, Lilje C, Läer S, Weil J (2006) Utility of $\mathrm{N}$-terminal brain natriuretic peptide plasma concentrations in comparison to lactate and troponin in children with congenital heart disease following open-heart surgery. Pediatr Cardiol 27:209-216

131. Kock A, Kitzsteiner T, Zink S, Cesnjevar R, Singer H (2007) Impact of cardiac surgery on plasma levels of B-type natriuretic peptide in children with congenital heart disease. Int J Cardiol 114:339-344

132. Gessler P, Knirsch W, Schmitt B, Rousson V, von Eckardstein A (2006) Prognostic value of plasma N-terminal pro-brain natriuretic peptide in children with congenital heart defects and open-heart surgery. J Pediatr 148:372-376

133. Niedner MF, Foley JL, Riffenburgh RH, Bichell DP, Peterson BM, Rodarte A (2010) B-type natriuretic peptide: peri-operative patterns in congenital heart disease. Congenit Heart Dis 5: 243-255

134. Amirnovin R, Keller RL, Herrera C, Hsu JH, Datar S, Karl TR, Adatia I, Oishi P, Fineman JR (2013) B-type natriuretic peptide levels predict outcomes in infants undergoing cardiac surgery in a lesion-dependent fashion. J Thorac Cardiovasc Surg 145: $1279-1287$

135. Cantinotti M, Clerico A, Iervasi G (2013) Age and disease related variations in BNP response after pediatric cardiac surgery. J Thorac Cardiovasc Surg 145:1415-1416

136. Cantinotti M, Lorenzoni V, Storti S, Moschetti R, Murzi B, Crocetti $\mathrm{M}$ et al (2012) Thyroid and BNP response in children undergoing cardiac surgery for congenital heart disease: age related variations and prognostic value. Circ J 77:188-197

137. Lindblade CL, Chun DS, Darragh RK, Caldwell RL, Murphy DJ, Schamberger MS (2005) Value of plasma B-type natriuretic peptide as a marker for rejection in pediatric heart transplant recipients. Am J Cardiol 95:909-911

138. Lan YT, Chang RK, Alejos JC, Burch C, Wetzel GT (2004) B-type natriuretic peptide in children after cardiac transplantation. J Heart Lung Transplant 23:558-563

139. Hammerer-Lercher A, Mair J, Antretter H, Ruttmann E, Poelzl G, Laufer G et al (2005) B-Type natriuretic peptide as a marker of allograft rejection after heart transplantation. J Heart Lung Transplant 24:1444e5-1448e8

140. Claudius I, Lan YT, Chang RK, Wetzel GT, Alejos J (2003) Usefulness of B-type natriuretic peptide as a noninvasive screening tool for cardiac allograft pathology in pediatric heart transplant recipients. Am J Cardiol 92:1368-1370

141. Ationu A, Burch M, Singer D, Littleton P, Carter N (1993) Cardiac transplantation affects ventricular expression of brain natriuretic peptide. Cardiovasc Res 27:188-189

142. Ationu A, Sorensen K, Whitehead B, Singer D, Burch M, Carter ND (1993) Ventricular expression of brain natriuretic peptide gene following orthotopic cardiac transplantation in children-a three year follow up. Cardiovasc Res 27:2135-2139 
143. Heise G, Lemmer J, Weng Y, Hübler M, Alexi-Meskishvili V, Böttcher W, Hetzer R, Berger F, Stiller B (2008) Biomarker responses during mid-term mechanical cardiac support in children. J Heart Lung Transplant 27:150-157

144. Cantinotti M, Clerico A, Iervasi G (2013) (2013) Age- and disease- related variations in B-type natriuretic peptide response after pediatric cardiac surgery. J Thorac Cardiovasc Surg 145: $1415-1416$

145. Cantinotti M, Vittorini S, Storti S, Prontera C, Murzi M, De Lucia V, Recla S, Assanta N, Giusti S, Murzi B, Bottone U, Clerico A (2009) Diagnostic accuracy and clinical relevance of brain natriuretic peptide assay in pediatric patients with congenital heart diseases. J Cardiovasc Med (Hagerstown) 10:706-713

146. Clerico A (2013) The increasing impact of laboratory medicine on clinical cardiology. Clin Chem Lab Med 41:871-883
147. Rifai N, Gillette MA, Carr SA (2006) Protein biomarker discovery and validation: the long and uncertain path to clinical utility. Nat Biotechnol 24:971-983

148. Maher KO, Reed H, Cuadrado A, Simsic J, Mahle WT, Deguzman M, Leong T, Bandyopadhyay S (2008) B-type natriuretic peptide in the emergency diagnosis of critical heart disease in children. Pediatrics 121:e1484-e1488

149. Saab FG, Aboulhosn JA (2013) Hemodynamic characteristics of cyanotic adults with single-ventricle physiology without Fontan completion. Congenit Heart Dis 8:124-130

150. Patel MS, Berg AM, Vincent RN, Mahle WT (2010) Serum parameters and echocardiographic predictors of death or need for transplant in newborns, children, and young adults with heart failure. Am J Cardiol 105:1798-1801 